\title{
Genetic Diversity and Population Structure of Chinese Corylus heterophylla and Corylus kweichowensis Using Simple Sequence Repeat Markers
}

\author{
Tiantian Zhao, Wenxu Ma, Qinghua Ma, Zhen Yang, Lisong Liang, and Guixi Wang \\ Key Laboratory of Tree Breeding and Cultivation of the State Forestry and Grassland Administration, \\ Beijing 100091, China; and Research Institute of Forestry, Chinese Academy of Forestry, No.1 \\ Dongxiaofu, Xiangshan Road, Haidian District, Beijing, 100091, China \\ Lujun Wang \\ Key Laboratory of Tree Breeding and Cultivation of the State Forestry and Grassland Administration, \\ Beijing 100091, China; Research Institute of Forestry, Chinese Academy of Forestry, No.1 \\ Dongxiaofu, Xiangshan Road, Haidian District, Beijing, 100091, China; and Anhui Academy of \\ Forestry, 820 Changjiang West Road, Shushan District, Hefei, Anhui Province, 230031, China
}

\begin{abstract}
AdDITIONAL INDEX wORDs. hazelnut, genetic variability, genetic differentiation, molecular markers, protection strategy, SSR
Abstract. Corylus heterophylla and Corylus kweichowensis are economically and ecologically important nutproducing woody shrubs that are distributed across northern and southern regions of China. However, few studies have examined the genetic diversity and genetic relationships between $C$. heterophylla and $C$. kweichowensis, and their taxonomic relationships have been questioned. In this study, 796 individuals collected from 34 natural populations (21 C. heterophylla and 13 C. kweichowensis populations) were investigated to assess the genetic diversity and population structure using 11 microsatellite loci. Analysis of molecular variance revealed that genetic differentiation of $C$. heterophylla and $C$. kweichowensis within populations accounted for $93.57 \%$ and $88.91 \%$ of total variation, respectively. The $C$. heterophylla and $C$. kweichowensis populations as a whole group were analyzed by multiple programs, which showed that the 34 populations were divided into two genetic clusters. One cluster included $21 C$. heterophylla populations, and the second cluster contained $13 \mathrm{C}$. kweichowensis populations. We conclude from these results that $C$. heterophylla and $C$. kweichowensis are distinct species. The Mantel test showed that the genetic distance was significantly correlated with the geographic distance $(r=0.580, P<0.001)$. The populations of $C$. heterophylla [e.g., populations WC (Weichang), MS (Mishan), and WA (Wu'an)] and C. kweichowensis [e.g., populations YX (Yuexi), ZP (Zhenping), LA (Lin'an), and TB (Taibai)] with high allelic richness are considered suitable for in situ conservation. Our study provides valuable information for breeding and conservation of genetic resources of $C$. heterophylla, $C$. kweichowensis, and related species.
\end{abstract}

Hazelnuts, of the family Betulaceae, are deciduous windpollinated, monoecious, self-incompatible nut-bearing shrubs (Gürcan et al., 2010a). More than 20 species have been described that are widely distributed throughout temperate regions of the Northern Hemisphere (Bassil et al., 2005). Hazelnut is one of the most important nut crops in the word and its production was 1,006,178 t in 2017 (Food and Agriculture Organization of the United Nations, 2017). Eight species and two botanical varieties of Corylus are reported to be native to China (Zhang et al., 2005), where their nuts have been collected as food for more than 5000 years (Martins et al., 2014). C. heterophylla grows throughout Korea, Japan, China,

Received for publication 12 Dec. 2019. Accepted for publication 21 May 2020. Published online 23 June 2020.

We thank the Special Fund of Basic Scientific Research Business of Central Public Research Institutes (Grant No. CAFYBB2017ZA004-9 and RIF-12) for funding this work.

We also thank Dr. Jianwei Zong for statistical advice.

Lujun Wang is the corresponding author.

E-mail: wanglujun1984@163.com.

This is an open access article distributed under the CC BY-NC-ND license (https://creativecommons.org/licenses/by-nc-nd/4.0/). and the Russian Far East. However, C. kweichowensis is native only to parts of China. There are significant differences between $C$. heterophylla and $C$. kweichowensis with regard to their distribution and habitat in China (Supplemental Table 1) (Ma et al., 2014). Corylus heterophylla is mainly distributed in northern areas of China, growing in locations with cold and dry environments, whereas C. kweichowensis grows in warm and moist environments, primarily in southern China (Liang, 1988). Among the different hazelnut species, $C$. heterophylla and $C$. $k$ weichowensis share a number of similar traits, and there is not a consensus among taxonomists that these two are distinct species. Based on morphological characteristics (Fig. 1), some taxonomists considered $C$. kweichowensis a botanical variety (var. sutchuensis) of C. heterophylla (Chen, 1953; Zheng, 1985), but other researchers thought that $C$. kweichowensis should be an independent species (Supplemental Table 2) (Qi, 1996; Zhang et al., 2005). Morphological descriptors have traditionally been used to identify hazelnut species, accessions, and cultivars; however, expression of such factors can be influenced by the environment. In recent years, molecular markers have been widely applied to study the genetic diversity and population structure of hazelnut, such as random amplified 

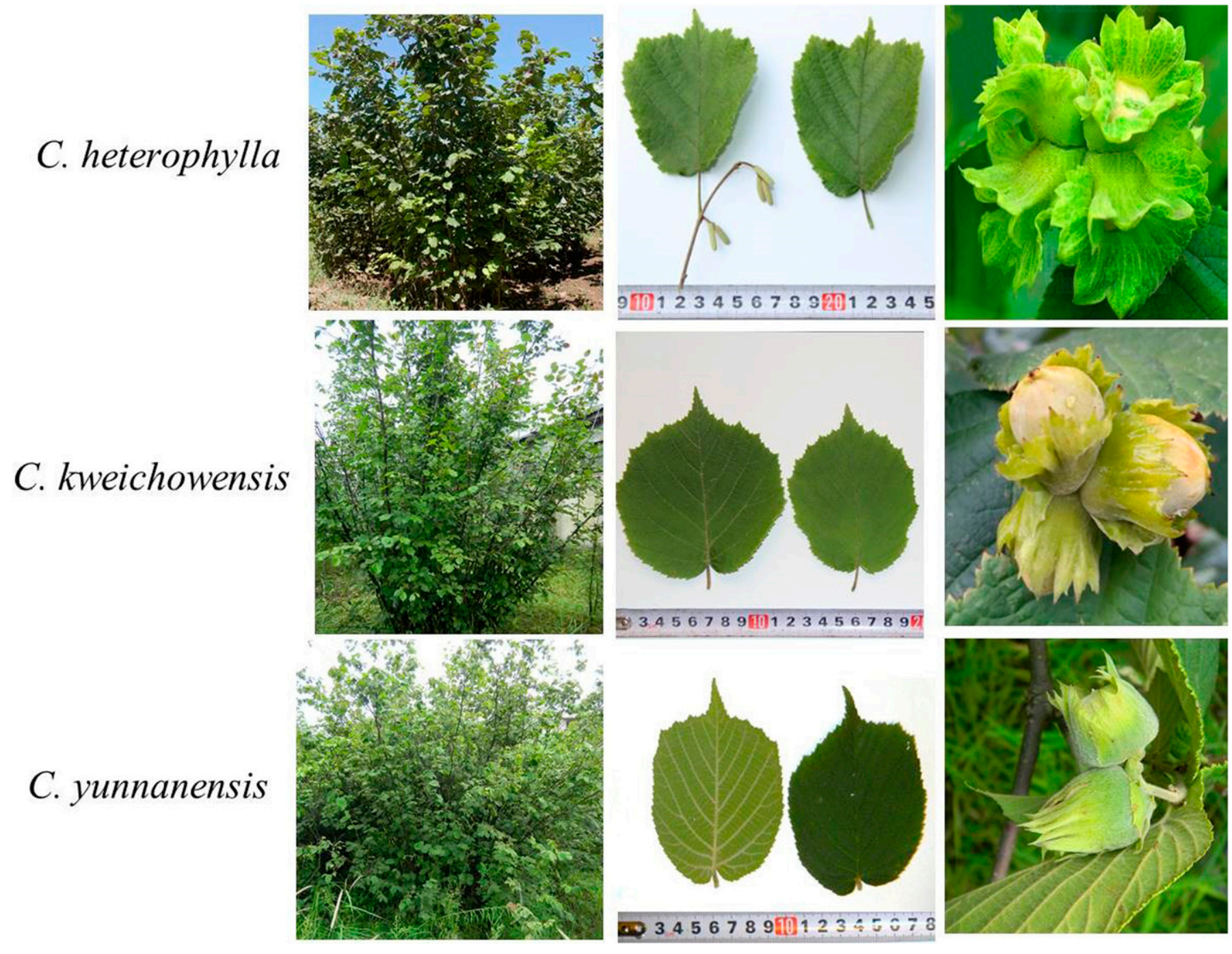

Fig. 1. Trees, leaves, and nuts with husk of Corylus heterophylla, Corylus kweichowensis, and Corylus yunnanensis.

polymorphic DNA [RAPD (Galderisi et al., 1999; Miaja et al., 2001)], simple sequence repeat [SSR (Boccacci et al., 2006, 2008; Gökirmak et al., 2009; Gürcan et al., 2010b; Zong et al., 2015)], intersimple sequence repeat [ISSR (Kafkas et al., 2009)], and amplified fragment length polymorphism [AFLP (Ferrari et al., 2005; Martins et al., 2014)], owing to their high discriminatory power and relatively low cost. Among the various kinds of markers, microsatellite or SSR has been demonstrated to be extremely effective for estimating genetic diversity for Corylus avellana and related species (Bassil et al., 2005, 2013). SSR markers, which are widely present in eukaryotic genomes (Sharma et al., 2007), are simple tandemly repeated DNA sequences. The advantages of SSR markers include codominant inheritance, high polymorphism, and suitability for sharing among laboratories, as well as cross-species transferability (Barbará et al., 2007). More recently, chloroplast genome and whole genome sequencing have been applied to plant classification and genetic evolution research (Rowley et al., 2018; Yang et al., 2019), but the evolutionary rate of the chloroplast genome sequence is slow, which is not suitable for the study of genetic relationships of related species, whereas whole genome sequencing is less applied to the study of genetic diversity of large-scale populations because of its high cost and workload. In this study, we investigated the genetic diversity and population structure of 21 populations of $C$. heterophylla and 13 populations of $C$. kweichowensis to clarify their taxonomic relationship and develop a strategy for conservation.

\section{Materials and Methods}

Plant materials and DNA extraction. A total of 796 wild samples, representing 34 populations, were collected throughout their native distributions in China. A map of the sampling locations was drawn using ArcGIS 10.0 (Esri, Redlands, CA) (Fig. 2). Of the 796 samples, 509 individuals representing 21 populations of $C$. heterophylla were collected from the northeast and north of China, and 287 samples were collected from 13 populations of $C$. kweichowensis across the south of China (Table 1). The distance between any two individuals at each location was more than $100 \mathrm{~m}$. Young and healthy fresh leaves were only collected from one independent shoot per plant and dried with silica gel, and then transported to the laboratory for subsequent DNA extraction using a modified CTAB procedure (Doyle and Doyle, 1987). 


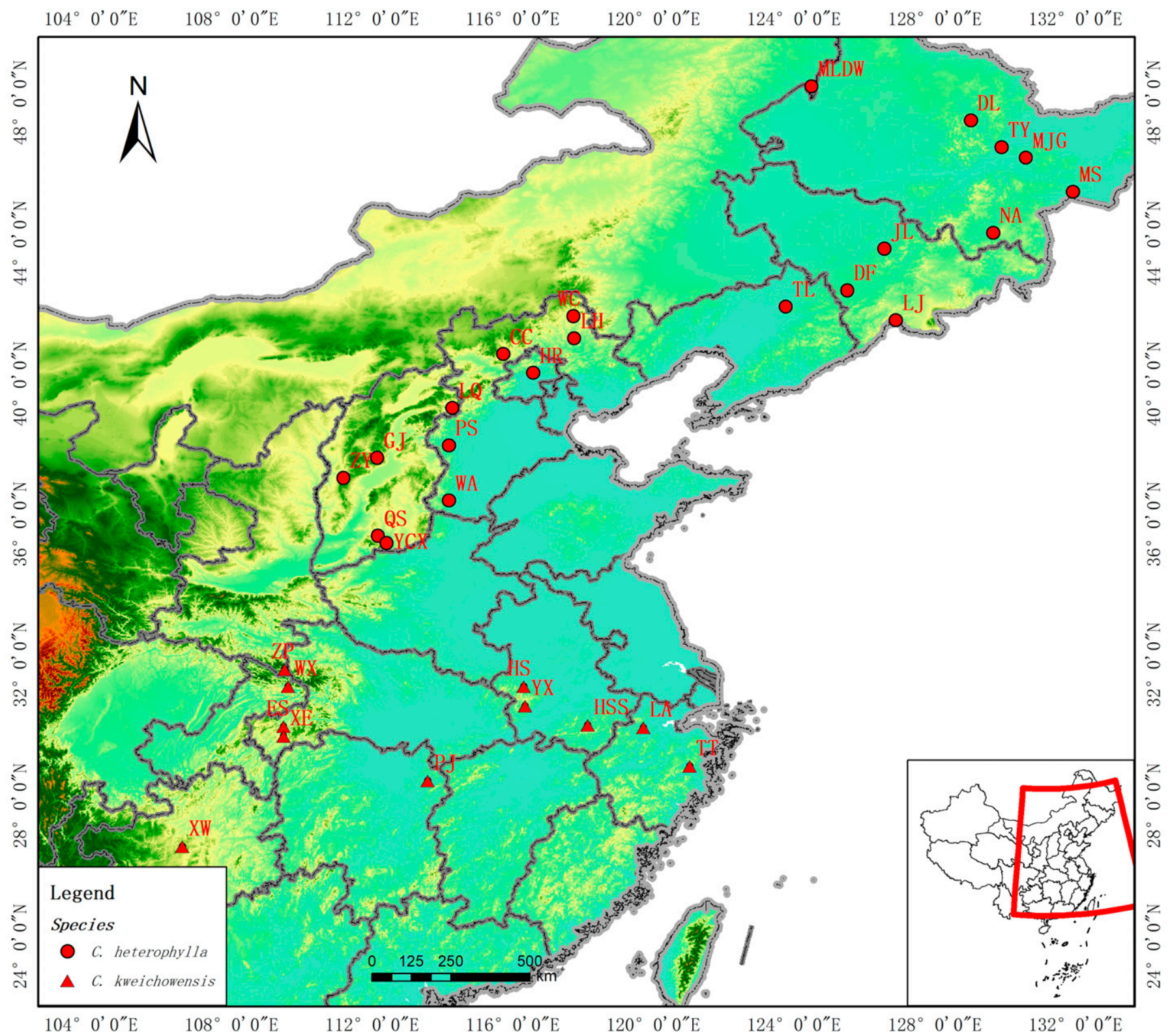

Fig. 2. Geographic distributions of 34 Corylus heterophylla and Corylus kweichowensis populations sampled in mainland China. The map of the sampling locations was drawn using ArcGIS 10.0 (Esri, Redlands, CA). The population codes are listed in Table 1.

Microsatellite DNA analysis. Eleven microsatellite loci were amplified and the results used to study the genetic diversity of C. heterophylla and C. kweichowensis. Sixty-five SSR markers, previously developed for hazelnut, were tested for their ability to produce amplification products in the two Corylus species. Then, 11 microsatellite loci with clear amplicons were finally selected to validate genetic diversity (Supplemental Table 3) (Bassil et al., 2005; Sathuvalli and Mehlenbacher, 2013). Polymerase chain reaction (PCR) amplifications were carried out in $20.0-\mu \mathrm{L}$ reactions. Each reaction contained $2.0 \mu \mathrm{L}$ DNA, $0.3 \mu \mathrm{L}$ of the forward primer $(20 \mu \mathrm{M})$, $0.3 \mu \mathrm{L}$ of the reverse primer $(20 \mu \mathrm{M}), 0.4 \mu \mathrm{L}$ dNTPs, $2.0 \mu \mathrm{L}$ PCR buffer, $0.2 \mu \mathrm{L}$ Taq polymerase, and $14.8 \mu \mathrm{L}$ doubled distilled water. PCR amplification was performed under the following conditions: $94{ }^{\circ} \mathrm{C}$ for $5 \mathrm{~min}$, followed by 35 cycles of $94{ }^{\circ} \mathrm{C}$ for $30 \mathrm{~s}$, annealing at 48 to $60{ }^{\circ} \mathrm{C}$ for $40 \mathrm{~s}, 72{ }^{\circ} \mathrm{C}$ for $40 \mathrm{~s}$, with a final extension at $72{ }^{\circ} \mathrm{C}$ for $3 \mathrm{~min}$. The forward primers were labeled with a fluorochrome (FAM or HEX). The products were analyzed using a capillary electrophoresis instrument (Applied Biosystems 3730xl; Thermo Fisher Scientific, Waltham, MA) and separated along with an internal size standard (Applied Biosystems GeneScan-500 LIZ, Thermo Fisher Scientific). The amplified fragments were sized using GENEMAPPER 4.0 software (Applied Biosystems, Thermo Fisher Scientific).

Data Analysis. The level of genetic diversity was calculated using Popgene 32 software (Yeh et al., 1999) with the following statistics: number of alleles $(\mathrm{Na})$, number of rare alleles $(\mathrm{Nr})$, number of effective alleles $(\mathrm{Ne})$, Shannon's information index $(I)$, observed heterozygosity $(\mathrm{Ho})$, expected heterozygosity $(\mathrm{He})$, polymorphism information content $(P I C)$, coefficient of inbreeding $\left(F_{i s}\right)$, genetic differentiation 
Table 1. Corylus heterophylla and Corylus kweichowensis populations surveyed in China and their sample size, location, and geographical parameters.

\begin{tabular}{|c|c|c|c|c|c|}
\hline Population code & Corylus species & Individuals (no.) & Collection location & Latitude $\left({ }^{\circ} \mathrm{N}\right)$ & Longitude $\left({ }^{\circ} \mathrm{E}\right)$ \\
\hline NA & C. heterophylla & 29 & Ning'an, Heilongjiang Province & $44^{\circ} 18^{\prime}$ & $129^{\circ} 40^{\prime}$ \\
\hline TY & C. heterophylla & 30 & Tangyuan, Heilongjiang Province & $46^{\circ} 44^{\prime}$ & $129^{\circ} 54^{\prime}$ \\
\hline MJG & C. heterophylla & 20 & Mengjiagang, Heilongjiang Province & $46^{\circ} 26^{\prime}$ & $130^{\circ} 36^{\prime}$ \\
\hline MS & C. heterophylla & 29 & Mishan, Heilongjiang Province & $45^{\circ} 28^{\prime}$ & $131^{\circ} 56^{\prime}$ \\
\hline DL & C. heterophylla & 30 & Dailing, Heilongjiang Province & $47^{\circ} 03^{\prime}$ & $129^{\circ} 02^{\prime}$ \\
\hline JL & C. heterophylla & 25 & Jilin, Jilin Province & $43^{\circ} 51^{\prime}$ & $126^{\circ} 34^{\prime}$ \\
\hline DF & C. heterophylla & 12 & Dongfeng, Jilin Province & $42^{\circ} 40^{\prime}$ & $125^{\circ} 31^{\prime}$ \\
\hline LJ & C. heterophylla & 25 & Linjiang, Jilin Province & $41^{\circ} 49^{\prime}$ & $126^{\circ} 54^{\prime}$ \\
\hline TL & C. heterophylla & 29 & Tieling, Liaoning Province & $42^{\circ} 12^{\prime}$ & $123^{\circ} 46^{\prime}$ \\
\hline MLDW & C. heterophylla & 25 & Molidawa, Inner Mongolia & $48^{\circ} 28^{\prime}$ & $124^{\circ} 30^{\prime}$ \\
\hline $\mathrm{WC}$ & C. heterophylla & 30 & Weichang, Hebei Province & $41^{\circ} 56^{\prime}$ & $117^{\circ} 44 \mathrm{v}$ \\
\hline LH & C. heterophylla & 26 & Longhua, Hebei Province & $41^{\circ} 18^{\prime}$ & $117^{\circ} 45^{\prime}$ \\
\hline $\mathrm{CC}$ & C. heterophylla & 20 & Chicheng, Hebei Province & $40^{\circ} 51^{\prime}$ & $115^{\circ} 44^{\prime}$ \\
\hline PS & C. heterophylla & 25 & Pingshan, Hebei Province & $38^{\circ} 15^{\prime}$ & $114^{\circ} 11^{\prime}$ \\
\hline WA & C. heterophylla & 25 & Wu'an, Hebei Province & $36^{\circ} 41^{\prime}$ & $114^{\circ} 11^{\prime}$ \\
\hline HR & C. heterophylla & 17 & Huairou, Beijing & $40^{\circ} 19^{\prime}$ & $116^{\circ} 35^{\prime}$ \\
\hline LQ & C. heterophylla & 20 & Linqiu, Shanxi Province & $39^{\circ} 19^{\prime}$ & $114^{\circ} 17^{\prime}$ \\
\hline ZY & C. heterophylla & 10 & Zhongyang, Shanxi Province & $37^{\circ} 20^{\prime}$ & $111^{\circ} 11^{\prime}$ \\
\hline GJ & C. heterophylla & 30 & Gujiao, Shanxi Province & $37^{\circ} 54^{\prime}$ & $112^{\circ} 09^{\prime}$ \\
\hline QS & C. heterophylla & 22 & Qinshui, Shanxi Province & $35^{\circ} 41^{\prime}$ & $112^{\circ} 10^{\prime}$ \\
\hline YCX & C. heterophylla & 30 & Yangcheng, Shanxi Province & $35^{\circ} 29^{\prime}$ & $112^{\circ} 25^{\prime}$ \\
\hline $\mathrm{ZP}$ & C. kweichowensis & 21 & Zhenping, Shaanxi Province & $31^{\circ} 53^{\prime}$ & $109^{\circ} 31^{\prime}$ \\
\hline TB & C. kweichowensis & 18 & Taibai, Shaanxi Province & $34^{\circ} 04^{\prime}$ & $107^{\circ} 18^{\prime}$ \\
\hline ES & C. kweichowensis & 19 & Enshi, Hubei Province & $30^{\circ} 16^{\prime}$ & $109^{\circ} 29^{\prime}$ \\
\hline $\mathrm{XE}$ & C. kweichowensis & 19 & Xuan'en, Hubei Province & $29^{\circ} 59^{\prime}$ & $109^{\circ} 29^{\prime}$ \\
\hline LA & C. kweichowensis & 25 & Lin'an, Zhejiang Province & $30^{\circ} 14^{\prime}$ & $119^{\circ} 43^{\prime}$ \\
\hline $\mathrm{TT}$ & C. kweichowensis & 25 & Tiantai, Zhejiang Province & $29^{\circ} 08^{\prime}$ & $121^{\circ} 02^{\prime}$ \\
\hline PJ & C. kweichowensis & 24 & Pingjiang, Hunan Province & $28^{\circ} 43^{\prime}$ & $113^{\circ} 35^{\prime}$ \\
\hline HS & C. kweichowensis & 24 & Huogshan, Anhui Province & $31^{\circ} 24^{\prime}$ & $116^{\circ} 19^{\prime}$ \\
\hline YX & C. kweichowensis & 25 & Yuexi, Anhui Province & $30^{\circ} 51^{\prime}$ & $116^{\circ} 21^{\prime}$ \\
\hline HSS & C. kweichowensis & 24 & Huangshan, Anhui Province & $30^{\circ} 18^{\prime}$ & $118^{\circ} 08^{\prime}$ \\
\hline XW & C. kweichowensis & 24 & Xiuwen, Guizhou Province & $26^{\circ} 51^{\prime}$ & $106^{\circ} 36^{\prime}$ \\
\hline WX & C. kweichowensis & 25 & Wuxi, Sichuan Province & $31^{\circ} 24^{\prime}$ & $109^{\circ} 37^{\prime}$ \\
\hline LD & C. kweichowensis & 14 & Luding, Sichuan Province & $29^{\circ} 55^{\prime}$ & $102^{\circ} 14^{\prime}$ \\
\hline
\end{tabular}

coefficient $\left(F_{s t}\right)$, gene flow $(\mathrm{Nm})$ and Nei's genetic distance. $N m$ was estimated as $N m=0.25\left(1-F_{s t}\right) / F_{s t}(\mathrm{Nei}, 1972)$. The frequency of null alleles were calculated by CERVUS program version 3.07 (Kalinowski et al., 2007). Cluster analysis conducted using the unweighted pair group method with arithmetic mean (UPGMA) generated a Nei's genetic distance matrix, and a dendrogram was constructed using MEGA version 6 (Tamura et al., 2013). The number of homogeneous gene pools $(K)$ was evaluated with the software package STRUCTURE 2.3.4 (Evanno et al., 2005). The length of the burn-in period and number of Markov chain Monte Carlo repetitions after burn-in were both set to 100,000 . The algorithm was run 10 times for each $K$ value, from 1 to 30 for the $C$. heterophylla and $C$. kweichowensis populations. Using an ad hoc quantity constructed from the second-order rate of change of the likelihood function with respect to $K$, the distribution of $\Delta K$, where $\Delta K=$ mean $\left(\left|L{ }^{\prime \prime}(K)\right|\right) / s[L(K)]$, showed a clear peak at the true value of $K$ (Earl and Vonholdt, 2012). The observed genetic variation among and within populations was characterized by analysis of molecular variance (AMOVA) using ARLEQUIN version 3.5 (Hamrick and Godt, 1996). In addition, Nei's genetic distance and geographic distance (kilome- ters) were tested for correlation using the Mantel test using GENALEX 6.5 (Peakall and Smouse, 2012).

\section{Results}

Genetic Diversity AMONG THE LOCI. A total of 159 alleles were found among the $C$. heterophylla individuals, 92 of which were rare alleles with a frequency less than $1 \%$ (Table 2). $\mathrm{Na}$ per locus ranged from 8 to 24 , with an average of 14 . Ne varied from 2.47 to 10.39 , with an average of 6.55 . The average of $I$ was 2.05, varied from 1.24 to 2.60. Ho and $\mathrm{He}$ ranged from 0.57 to 0.84 , and 0.60 to 0.90 , with average values of 0.74 and 0.82 , respectively. The average $P I C$ value was 0.821 . Similarly, a total of 162 alleles were found in the 287 C. kweichowensis individuals, 92 of which were rare alleles (Table 3). $\mathrm{Na}$ varied from 9 to 23, with an average of 15 . Ne ranged from 2.59 to 10.56 , with an average of 6.42 . The average value of $I$ was 2.06 , ranging from 1.36 to 2.59 . The $H o$ in the total individuals was 0.67 , which deviated from the $\mathrm{He}(0.82)$, whereas $\mathrm{Ho}$ and $\mathrm{He}$ ranged from 0.43 to 0.84 , and 0.61 to 0.91 , respectively. The average $P I C$ value for $C$. kweichowensis was 0.802 . The mean value of the frequency of null alleles of $C$. kweichowensis was 
Table 2. List of 11 simple sequence repeat (SSR) loci used in the current study with number of alleles $(\mathrm{Na})$, number of rare alleles $(\mathrm{Nr})$, number of effective alleles $(\mathrm{Ne})$, Shannon's information index (I), observed heterozygosity ( $\mathrm{Ho}$ ), expected heterozygosity (He), polymorphism information content $(P I C)$, coefficient of inbreeding $\left(F_{i s}\right)$, genetic differentiation coefficient $\left(F_{s t}\right)$, gene flow $(\mathrm{Nm})$, and frequency of null alleles from 509 Corylus heterophylla individuals.

\begin{tabular}{|c|c|c|c|c|c|c|c|c|c|c|c|}
\hline Locus & $\mathrm{Na}$ & $\mathrm{Nr}$ & $\mathrm{Ne}$ & $I$ & Ho & $\mathrm{He}$ & $P I C$ & $F_{i s}$ & $F_{s t}$ & $\mathrm{Nm}$ & Null alleles (frequency) \\
\hline CAC-B005 & 18 & 12 & 6.74 & 2.26 & 0.78 & 0.85 & 0.838 & 0.041 & 0.055 & 4.312 & 0.049 \\
\hline CAC-B105 & 18 & 11 & 10.39 & 2.56 & 0.76 & 0.90 & 0.897 & 0.099 & 0.048 & 4.983 & 0.086 \\
\hline $\mathrm{CAC}-\mathrm{B} 001^{\mathrm{z}}$ & 14 & 7 & 7.28 & 2.21 & 0.84 & 0.86 & 0.849 & -0.029 & 0.052 & 4.609 & 0.015 \\
\hline CAC-B $113^{z}$ & 15 & 9 & 7.62 & 2.30 & 0.73 & 0.87 & 0.857 & 0.096 & 0.054 & 4.406 & 0.089 \\
\hline $\mathrm{CAC}-\mathrm{C} 003^{z}$ & 8 & 3 & 4.14 & 1.56 & 0.84 & 0.76 & 0.897 & 0.048 & 0.076 & 3.044 & 0.070 \\
\hline $\mathrm{CAC}-\mathrm{C} 028^{\mathrm{z}}$ & 9 & 5 & 2.47 & 1.24 & 0.57 & 0.60 & 0.557 & 0.024 & 0.034 & 7.135 & 0.020 \\
\hline LG637y & 16 & 9 & 7.22 & 2.26 & 0.57 & 0.86 & 0.894 & 0.275 & 0.097 & 2.336 & 0.207 \\
\hline LG639y & 24 & 15 & 10.10 & 2.60 & 0.83 & 0.90 & 0.894 & 0.025 & 0.059 & 4.027 & 0.046 \\
\hline Mean & 14 & 8 & 6.55 & 2.05 & 0.74 & 0.82 & 0.821 & 0.063 & 0.058 & 4.354 & 0.066 \\
\hline
\end{tabular}

${ }^{\mathrm{z}} \mathrm{SSR}$ primers developed by Bassil et al. (2005).

${ }^{\mathrm{y}} \mathrm{SSR}$ primers developed by Sathuvalli and Mehlenbacher (2013).

Table 3. List of 11 simple sequence repeat (SSR) loci used in the current study with number of alleles $(\mathrm{Na})$, number of rare alleles ( $\mathrm{Nr}$ ), number of effective alleles $(\mathrm{Ne})$, Shannon's information index $(I)$, observed heterozygosity $(\mathrm{Ho})$, expected heterozygosity (He), polymorphism information content $(P I C)$, coefficient of inbreeding $\left(F_{i s}\right)$, genetic differentiation coefficient $\left(F_{s t}\right)$, gene flow $(\mathrm{Nm})$, and frequency of null alleles from 287 Corylus kweichowensis individuals.

\begin{tabular}{|c|c|c|c|c|c|c|c|c|c|c|c|}
\hline Locus & $N a$ & $\mathrm{Nr}$ & $\mathrm{Ne}$ & $I$ & Ho & $\mathrm{He}$ & $P I C$ & $F_{i s}$ & $F_{s t}$ & $\mathrm{Nm}$ & Null alleles (frequency) \\
\hline$\overline{\mathrm{CAC}-\mathrm{B} 005^{\mathrm{z}}}$ & 18 & 10 & 6.32 & 2.22 & 0.72 & 0.84 & 0.828 & 0.021 & 0.132 & 1.639 & 0.077 \\
\hline CAC-B105 & 18 & 11 & 8.53 & 2.37 & 0.63 & 0.88 & 0.872 & 0.223 & 0.085 & 2.677 & 0.172 \\
\hline CAC-B $001^{z}$ & 17 & 12 & 6.17 & 2.15 & 0.78 & 0.84 & 0.822 & -0.010 & 0.086 & 2.674 & 0.037 \\
\hline CAC-B113 & 15 & 8 & 7.03 & 2.17 & 0.57 & 0.86 & 0.843 & 0.272 & 0.079 & 2.933 & 0.202 \\
\hline $\mathrm{CAC}-\mathrm{C} 003^{z}$ & 9 & 4 & 4.22 & 1.64 & 0.68 & 0.76 & 0.729 & 0.034 & 0.076 & 3.028 & 0.056 \\
\hline $\mathrm{CAC}-\mathrm{C} 028^{\mathrm{z}}$ & 10 & 6 & 2.59 & 1.36 & 0.58 & 0.61 & 0.584 & -0.033 & 0.081 & 2.835 & 0.018 \\
\hline LG628y & 10 & 3 & 6.35 & 1.98 & 0.68 & 0.84 & 0.824 & 0.132 & 0.078 & 2.945 & 0.111 \\
\hline LG637y & 15 & 7 & 8.76 & 2.36 & 0.43 & 0.89 & 0.875 & 0.444 & 0.114 & 1.953 & 0.343 \\
\hline LG639y & 23 & 14 & 10.56 & 2.59 & 0.84 & 0.91 & 0.898 & -0.005 & 0.088 & 2.578 & 0.038 \\
\hline Mean & 15 & 8 & 6.42 & 2.06 & 0.67 & 0.82 & 0.802 & 0.098 & 0.090 & 2.619 & 0.105 \\
\hline
\end{tabular}

${ }^{\mathrm{z}}$ SSR primers developed by Bassil et al. (2005).

${ }^{\mathrm{y}}$ SSR primers developed by Sathuvalli and Mehlenbacher (2013).

0.105 , whereas that of $C$. heterophylla was 0.066 . The highest frequency values of null alleles at Locus LG637 for $C$. heterophylla and $C$. kweichowensis were 0.207 and 0.343, respectively (Tables 2 and 3). Thirteen and 20 unique alleles were found in the $C$. heterophylla and $C$. kweichowensis populations, respectively (Supplemental Table 4). In C. heterophylla, the number of unique alleles per locus ranged from one to three with the highest number at locus CAC-B028. In $C$. $k$ weichowensis, the highest number of unique alleles (five) was at locus CAC-B001. In C. heterophylla, no unique alleles were detected at CAC-B105, CAC-B001, and LG612, whereas in $C$. kweichowensis no unique alleles were detected at LG628 (Supplemental Table 4).

Genetic Diversity AMONG THE POPUlations. Among the 21 C. heterophylla populations, the higher degree of genetic diversity occurred in WC (Weichang, Hebei Province), MS (Mishan, Heilongjiang Province), and WA (Wu'an, Hebei Province), whereas the lowest level of diversity was observed in ZY (Zhongyang, Shanxi Province) (Table 4). Among the 13 C. kweichowensis populations, YX (Yuexi, Anhui Province), ZP (Zhenping, Shaanxi Province), LA (Lin'an, Zhejiang Province), and TB (Taibai, Shaanxi Province) showed relatively higher genetic diversity than other populations, whereas the lowest diversity was in XE (Xuan'en, Hubei Province) (Table 4). $\mathrm{Ho}$ and $\mathrm{He}$ values in $\mathrm{C}$. heterophylla populations were slightly larger than those in $C$. kweichowensis populations (Table 4). However, regardless of whether they belonged to $C$. heterophylla populations or $C$. kweichowensis populations, the $H o$ values were significantly lower than the $H e$ values except for the ZY and JL (Jilin, Jilin Province) populations.

Genetic Differentiation. The inbreeding coefficient $\left(F_{i s}\right)$ values per locus of the $C$. heterophylla populations ranged from -0.045 to 0.275 , with an average of 0.063 (Table 2). The average $F_{s t}$ value was 0.058 , and varied from 0.034 to 0.097 , indicating that genetic variation within populations $(94.13 \%)$ was higher than that of among populations (5.87\%). AMOVA 
revealed that genetic variation within $C$. heterophylla populations accounted for $93.57 \%$ of the total variation (Table 5). The average $\mathrm{Nm}$ value was 4.354 (Table 2). Among the $13 \mathrm{C}$. $k$ weichowensis populations, the $F_{i s}$ value ranged from -0.033 to 0.444 , with an average of $0.098 . F_{s t}$ value varied from 0.076 to 0.132 , with an average of 0.090 (Table 3 ). As was the case with $C$. heterophylla, we detected genetic variation within the $C$.

Table 4. Genetic diversity within 21 Corylus heterophylla populations and 13 Corylus kweichowensis populations.

\begin{tabular}{|c|c|c|c|c|c|c|}
\hline $\begin{array}{l}\text { Population } \\
\text { code }^{z}\end{array}$ & Corylus species & $N a^{\mathrm{y}}$ & $N e^{\mathrm{y}}$ & $H o^{\mathrm{y}}$ & $H e^{\mathrm{y}}$ & $I^{\mathrm{y}}$ \\
\hline NA & C. heterophylla & 8 & 4.97 & 0.70 & 0.78 & 1.76 \\
\hline TY & C. heterophylla & 8 & 4.59 & 0.70 & 0.76 & 1.72 \\
\hline MJG & C. heterophylla & 7 & 4.06 & 0.67 & 0.71 & 1.57 \\
\hline MS & C. heterophylla & 10 & 5.89 & 0.72 & 0.80 & 1.88 \\
\hline DL & C. heterophylla & 9 & 4.91 & 0.67 & 0.77 & 1.74 \\
\hline TL & C. heterophylla & 9 & 5.34 & 0.68 & 0.79 & 1.84 \\
\hline WC & C. heterophylla & 10 & 5.93 & 0.75 & 0.80 & 1.89 \\
\hline LH & C. heterophylla & 9 & 5.10 & 0.75 & 0.79 & 1.79 \\
\hline $\mathrm{CC}$ & C. heterophylla & 9 & 5.89 & 0.73 & 0.79 & 1.86 \\
\hline HR & C. heterophylla & 8 & 5.01 & 0.72 & 0.78 & 1.77 \\
\hline LQ & C. heterophylla & 9 & 5.38 & 0.76 & 0.78 & 1.81 \\
\hline ZY & C. heterophylla & 5 & 3.59 & 0.75 & 0.70 & 1.40 \\
\hline GJ & C. heterophylla & 10 & 5.70 & 0.72 & 0.79 & 1.87 \\
\hline QS & C. heterophylla & 9 & 5.03 & 0.70 & 0.77 & 1.77 \\
\hline YCX & C. heterophylla & 9 & 5.06 & 0.75 & 0.77 & 1.75 \\
\hline $\mathrm{DF}$ & C. heterophylla & 8 & 4.97 & 0.75 & 0.78 & 1.75 \\
\hline MLDW & C. heterophylla & 8 & 5.51 & 0.75 & 0.79 & 1.80 \\
\hline $\mathrm{JL}$ & C. heterophylla & 8 & 4.38 & 0.74 & 0.72 & 1.59 \\
\hline LJ & C. heterophylla & 9 & 5.65 & 0.76 & 0.79 & 1.86 \\
\hline PS & C. heterophylla & 9 & 5.02 & 0.74 & 0.77 & 1.75 \\
\hline WA & C. heterophylla & 9 & 5.76 & 0.68 & 0.80 & 1.87 \\
\hline ZP & C. kweichowensis & 9 & 5.22 & 0.76 & 0.78 & 1.81 \\
\hline TB & C. kweichowensis & 8 & 5.59 & 0.72 & 0.78 & 1.81 \\
\hline ES & C. kweichowensis & 8 & 5.01 & 0.67 & 0.78 & 1.76 \\
\hline $\mathrm{XE}$ & C. kweichowensis & 5 & 3.08 & 0.65 & 0.65 & 1.25 \\
\hline LA & C. kweichowensis & 9 & 5.31 & 0.63 & 0.78 & 1.82 \\
\hline $\mathrm{TT}$ & C. kweichowensis & 7 & 3.78 & 0.61 & 0.70 & 1.49 \\
\hline PJ & C. kweichowensis & 7 & 4.54 & 0.63 & 0.76 & 1.64 \\
\hline HS & C. kweichowensis & 8 & 4.53 & 0.69 & 0.77 & 1.71 \\
\hline YX & C. kweichowensis & 9 & 5.54 & 0.65 & 0.79 & 1.87 \\
\hline HSS & C. kweichowensis & 8 & 4.76 & 0.71 & 0.76 & 1.68 \\
\hline XW & C. kweichowensis & 9 & 5.07 & 0.69 & 0.77 & 1.77 \\
\hline WX & C. kweichowensis & 8 & 4.58 & 0.64 & 0.72 & 1.62 \\
\hline LD & C. kweichowensis & 6 & 3.68 & 0.68 & 0.69 & 1.44 \\
\hline
\end{tabular}

${ }^{\mathrm{z}}$ The population codes are listed in Table 1 .

${ }^{\mathrm{y}} \mathrm{Na}=$ number of alleles; $\mathrm{Ne}=$ number of effective alleles; $\mathrm{Ho}=$ observed heterozygosity; $\mathrm{He}=$ expected heterozygosity; $I=$ Shannon's information index. kweichowensis populations, which in this case accounted for $91.51 \%$ of the total variation. AMOVA showed that variation within populations was $88.91 \%$ of the total variation, while variation among populations was $11.09 \%$ of the total variation (Table 5). The variation within populations is higher than that among populations, possibly because of the relatively high gene flow of $C$. heterophylla populations $(N m=4.354)$ and $C$. kweichowensis populations $(\mathrm{Nm}=2.619)$.

Genetic Structure among populations. Based on Nei's genetic distance using UPGMA, the 21 C. heterophylla populations and $13 C$. kweichowensis populations were grouped and analyzed as a whole (Fig. 3). The populations were divided into four groups. Group I contained 21 populations of C. heterophylla; group II consisted of $11 \mathrm{C}$. kweichowensis populations, and both group III and group IV contained a single population each, where the LD (Luding, Sichuan Province) population and the XE population belonged to $C$. kweichowensis. The results showed distinct genetic differentiation between C. heterophylla and C. kweichowensis, reflecting to their different geographical distribution area.

The total populations were evaluated by Bayesian-based population assignment analysis using STRUCTURE 2.3.4 (Fig. 4). LnP (D) showed substantial fluctuation during $K=1$ and $K=$ 2 . The $\Delta K$ showed a clear maximum for $K=2(\Delta K=113.94)$, indicating that the 34 populations were classified into two groups: Group I included 21 populations of $C$. heterophylla, and group II contained 13 populations of $C$. kweichowensis (Fig. 4). These results suggested differentiation between the two groups, and grouped them by species.

The 34 populations were also investigated by principal coordinate analysis (PCoA) using GenALEx 6.5. This gave a similar result to the UPGMA and STRUCTURE analyses. The populations were divided into two groups, with the $C$. heterophylla populations in one group and the $C$. kweichowensis populations in the other. The first main coordinates and the second main coordinates explained $41.99 \%$ and $18.02 \%$ of the total variance, respectively (Fig. 5). An analysis based on the Mantel test (Fig. 6) showed that the genetic distance was significantly correlated with the geographic distance $(r=0.580, P<0.001)$, but the correlation was relatively low, suggesting that geographic distance influences genetic differentiation between $C$. heterophylla and C. kweichowensis.

\section{Discussion}

Genetic Diversity. The mean $N a$ of $C$. kweichowensis and C. heterophylla are close to that of Corylus mandshurica (Zong et al., 2015), but significantly higher than that of $C$. avellana (Bassil et al., 2005). Perhaps because it compared with 13 unique alleles found in the population of $C$. heterophylla, 20

Table 5. Analysis of molecular variance (AMOVA) of genetic diversity of populations.

\begin{tabular}{|c|c|c|c|c|c|c|}
\hline Corylus species & Source of variation & $\mathrm{df}$ & Sum of squares & Variance components & Proportion of variation $(\%)$ & $P$ \\
\hline \multirow[t]{2}{*}{ Corylus heterophylla } & Among populations & 20 & 568.02 & 25.52 & 6.43 & $<0.001$ \\
\hline & Within populations & 488 & 4562.27 & 9.59 & 93.57 & $<0.001$ \\
\hline Corylus kweichowensis & Among populations & 12 & 436.63 & 36.39 & 11.09 & $<0.001$ \\
\hline Corylus heterophylla and & Among populations & 33 & 1174.41 & 35.59 & 10.33 & $<0.001$ \\
\hline Corylus kweichowensis & Within populations & 762 & 7342.87 & 9.64 & 89.67 & $<0.001$ \\
\hline
\end{tabular}




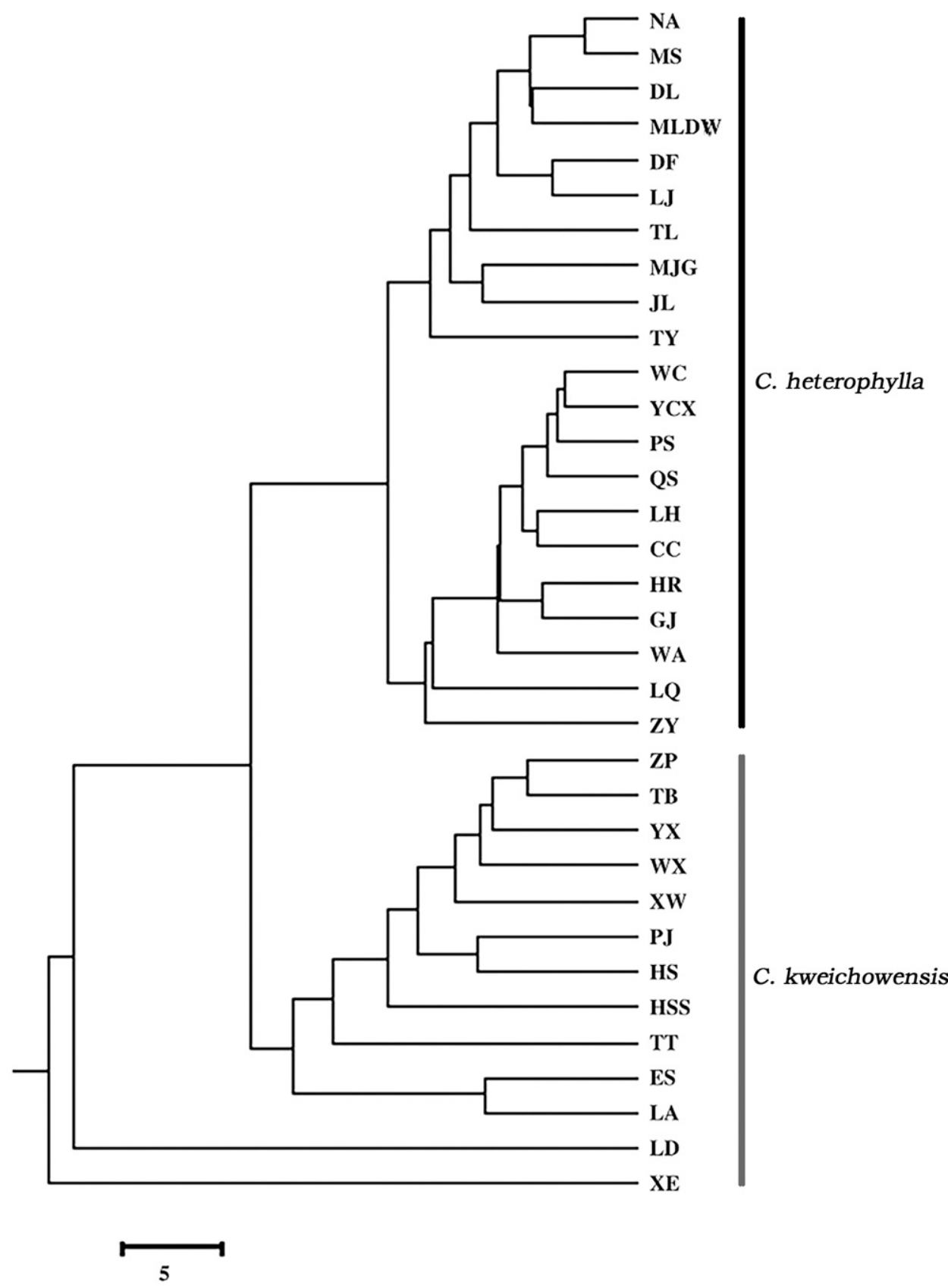

Fig. 3. Unweighted pair group method with arithmetic mean (UPGMA) dendrogram of 34 populations of Corylus heterophylla and Corylus kweichowensis based on Nei's genetic distance. The population codes are listed in Table 1 .

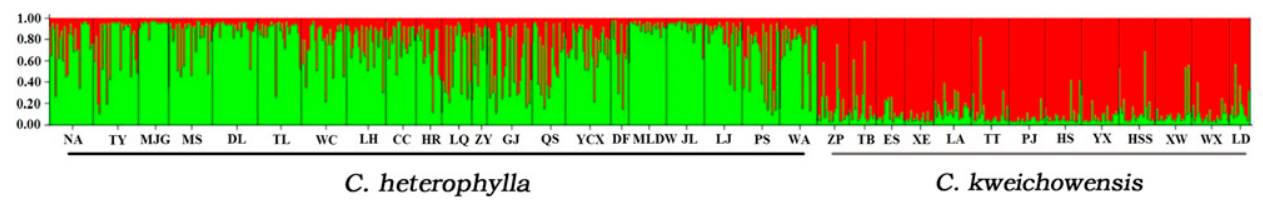

Fig. 4. Bayesian STRUCTURE bar plots of membership for 34 Corylus heterophylla and Corylus kweichowensis populations $(K=2)$ based on simple sequence repeat (SSR) markers. The population codes are listed in Table 1; $K=$ number of homogeneous gene pools, $\Delta K=$ mean $\left(\left|L^{\prime \prime}(K)\right|\right) / s[L(K)]$.

unique alleles were found in the $C$. kweichowensis populations with fewer samples (Supplemental Table 4). The results showed that the population of $C$. kweichowensis had higher allele richness. Heterozygosity is an important parameter in determining genetic diversity. In a previous study of $C$. heterophylla and $C$. kweichowensis collected from Hebei and Henan Provinces of China, Wang et al. (2008) reported $\mathrm{Ho}$ and $\mathrm{He}$ values for $\mathrm{C}$. heterophylla and $C$. kweichowensis of 0.52 and 0.66 , and 0.48 and 0.58 , respectively. For C. mandshurica growing in China, Zong et al. (2015) reported $\mathrm{Ho}$ and $\mathrm{He}$ values of 0.67 and 0.78 , respectively. Polymorphism of 20 $C$. avellana genotypes and seven Corylus species, including Corylus colurna, Corylus chinensis, Corylus heterophylla, Corylus americana, Corylus californica, Corylus fargesii, and Corylus ferox, were investigated by Bassil et al. (2005), where the average values for $C$. avellana were $\mathrm{Ho}(0.62)$ and $\mathrm{He}(0.68)$. When the eight species genotypes were included, the average $\mathrm{Ho}$ and $\mathrm{He}$ values were 0.59 and 0.78 , respectively. Sathuvalli and Mehlenbacher (2012) studied the genetic diversity of 87 C. americana populations using SSR markers and observed a high level of genetic diversity $(\mathrm{Ho}=$ $0.68, H e=0.74)$. Demchik et al. (2018) found a similar result that there was a highly heterozygous for 25 C. americana accessions, with $0.69(\mathrm{Ho})$ and $0.78(\mathrm{He})$, in the upper midwestern United States. Compared with these related studies, our results indicate a relatively higher level of genetic diversity, as the mean $\mathrm{Ho}$ and $\mathrm{He}$ values for $\mathrm{C}$. heterophylla were 0.74 and 0.82 , respectively, and 0.67 and 0.82 for C. kweichowensis, respectively. We suggest that this difference in the apparent degree of diversity is due to our samples being collected from wider ranges in China. Moreover, it was also important to use appropriate SSR markers in the study. After all, different markers may give different values in the same plant accessions. Michalski and Durka (2007) reported the mean values for $\mathrm{Ho}$ and $\mathrm{He}$ in Juncus atratus as 0.48 and 0.58 , respectively. The lower value for $\mathrm{Ho}$ was attributed to the frequency of self-pollination in this species. Our results further reveal that both $C$. heterophylla and $C$. kweichowensis show substantial genetic variation: the $H o$ values were lower than the $H e$ values at the microsatellite loci, with the only exception 
Principal Coordinates

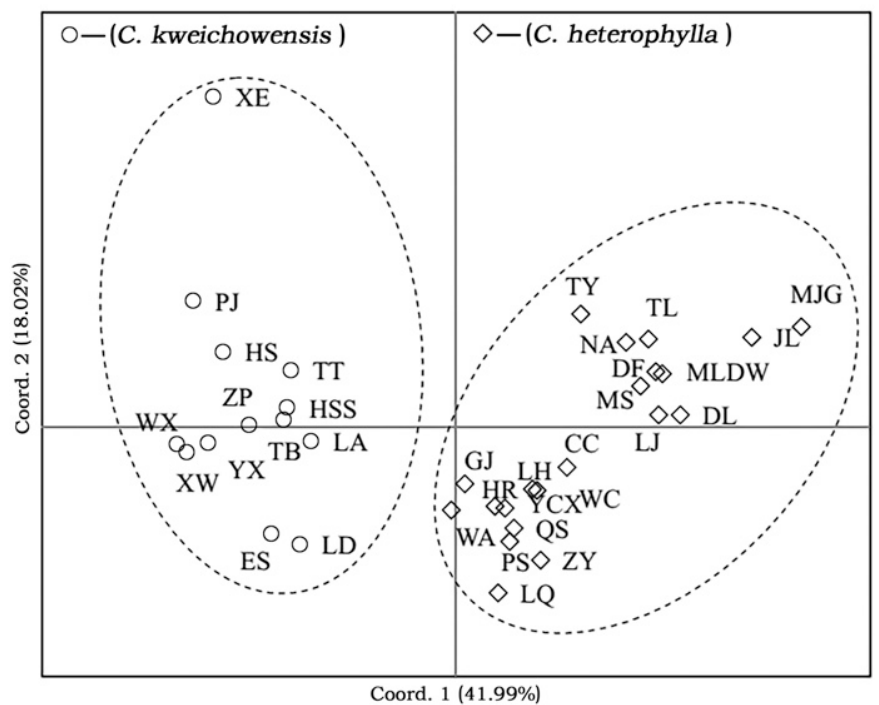

Fig. 5. Principal coordinate analysis (PCoA) based on simple sequence repeat (SSR) markers using the genetic distance matrix for distribution of the 34 Corylus heterophylla and Corylus kweichowensis populations in China. The population codes are listed in Table 1.

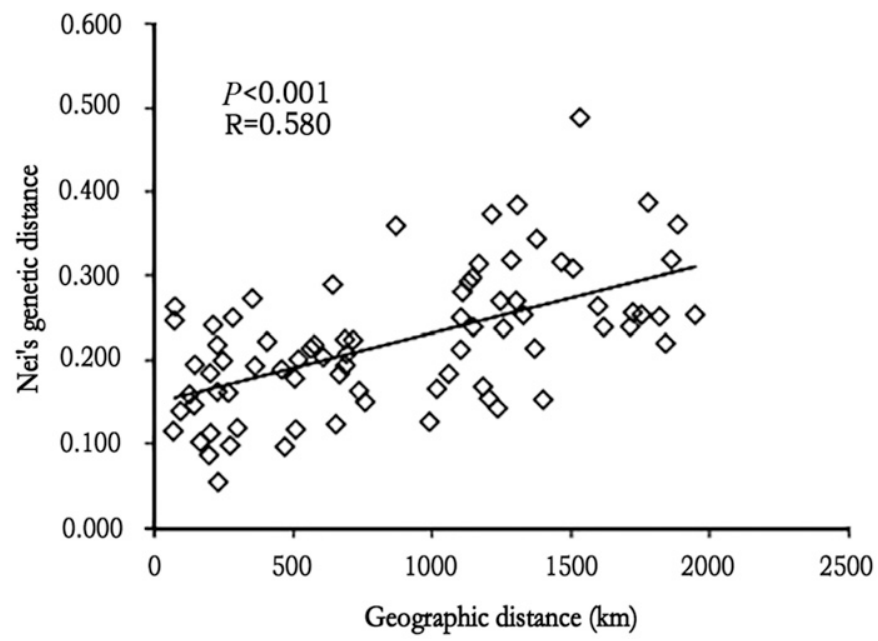

Fig. 6. Mantel test for matrix correlation between Nei's genetic distance and geographic distance for 34 Corylus heterophylla and Corylus kweichowensis populations.

being CAC-C003 in C. heterophylla (Table 2), indicating low heterozygosity at these loci. These results indicated a low level of inbreeding. The diversity level expressed an uneven and irregular distribution among C. heterophylla and C. kweichowensis populations. For instance, adjacent populations such as DL, TY, MJG, and MS from Heilongjiang Province of $C$. heterophylla and HS, YX, and HSS from Anhui Province of $C$. kweichowensis exhibited significant differences in genetic diversity, whereas four allopatric populations of C. heterophylla (NA from Heilongiiang Province, DF from Jilin Province, PS from Hebei Province, and YCX from Shanxi Province) and two populations of $C$. kweichowensis (ZP from Shaaxi Province, and LA from Zhejiang Province) showed nearly identical levels. The reason for this phenomenon may largely be attrib- uted to spatially different ecological environments which facilitate the genetic variation at different levels.

GENETIC DIFFERENTIATION AND GENE FLOW. The $F_{s t}$ values of C. heterophylla and C. kweichowensis indicated that most of the total genetic variation resided within populations, rather than among populations (Tables 2 and 3). Compared with other Corylus species, the results agreed with those for C. mandshurica (Zong et al., 2015) and for C. avellana (Gürcan et al., $2010 \mathrm{~b}) . F_{s t}$ values of 25 C. americana accessions were evaluated by Demchik et al. (2018), and varied from 0.02 to 0.19 , with a mean value of 0.12 , which further supported high levels of genetic diversity within populations. Wright (1978) suggested that $F_{s t}$ values of between 0.05 and 0.15 were indicative of moderate genetic differentiation. Our results indicated that the genetic differentiation of $C$. heterophylla was slightly lower than that of $C$. kweichowensis, while overall the two species showed a moderate level of genetic differentiation. Gene flow occurring within a species results in the movement of genes from one population to another (Slatkin, 1985; Slatkin and Barton, 1989), and is important in maintaining the genetic and phenotypic homogeneity of a species (Mayr, 1999). Slatkin (1985) proposed that if $\mathrm{Nm}>1$, the effect of genetic drift on population differentiation was reduced. In this study, the mean gene flow values of $C$. heterophylla and $C$. kweichowensis were 4.354 and 2.619, respectively, which suggests extensive gene flow in the different populations. The high level of gene flow for these two species may be related to wind-borne pollen and seed dispersal by birds and animals (Zhao et al., 2016). In addition, C. heterophylla has been used for thousands of years, whereas C. kweichowensis remains underused in China. Such factors may explain why the gene flow mean value of $C$. heterophylla is higher than that of $C$. kweichowensis. In a previous study, Zhao et al. (2016) evaluated the gene flow of $C$. heterophylla in Tieling, in Liaoning Province of China, and obtained a higher gene flow value up to 7.599. It may have been that the sampling range was less than the range used in our study, leading to a higher estimation of gene flow. The Mantel test showed that the genetic distance was significantly correlated with the geographic distance, and we observed that the gene flow among populations played a key role in genetic differentiation.

Genetic STRUCTURe AND RELATIONSHips BetWeen $\boldsymbol{C}$. HETEROPHYLLA AND C. KWEICHOWENSIS. An UPGMA dendrogram based on Nei's genetic distance showed that 34 populations were divided into two primary groups (Fig. 3). All 21 populations of $C$. heterophylla were clustered into one group, and 11 of the 13 populations of $C$. kweichowensis clustered together, whereas populations LD and XE were placed basal to all the other populations in the study (Fig. 3). We propose that the LD and XE populations may have encountered a barrier or have experienced habitat fragmentation, resulting in their deviation from the other 11 populations of $C$. kweichowensis. The STRUCTURE and PCoA analyses indicated that $C$. heterophylla and C. kweichowensis can be classified to two separate groups (Figs. 3 and 4), although they have many similar traits, such as nut size and shape. Based on our genetic diversity and structure analyses, we conclude that they are distinct species. Qi (1996) suggested that C. kweichowensis is a separate species based on a comparison of leaf and nut characteristics with those of related species, whereas $\mathrm{Ma}$ et al. (2014) also concluded that C. heterophylla and C. kweichowensis are distinct species based on geographic distribution and 
growth in different ecological conditions. Both are distributed across a wide range of climates and soils in China, with the former mainly distributed in northern regions of China, whereas the latter is mostly found in southern China, and the only intersecting region is located in the Qinling Mountains.

A better understanding of the genetic diversity of $C$. heterophylla and C. kweichowensis is important for wild resource conservation, breeding programs, and their utilization. Little is known about the genetic diversity and genetic erosion of wild Corylus species, with the exception C. mandshurica (Zong et al., 2015) and C. heterophylla (Zhao et al., 2016), and most studies have focused on cultivated $C$. avellana (Molnar, 2011). The loss of resources due to genetic erosion is intensifying as a consequence of overdevelopment and deforestation, as well as other causes. Ex situ and in situ conservation can be used to preserve germplasm resources, but as wild $C$. heterophylla and $C$. kweichowensis are widely distributed in China, thus, in situ conservation will likely be needed, requiring substantial investment and management. We suggest building a germplasm nursery or core collections for ex situ conservation where the resources will be collected from different distributed regions based on phenotype characteristics and molecular markers. There are examples of ex situ field collections of Corylus species, including $\approx 320$ named cultivars, selections, and rootstocks that have been preserved at the U.S. Department of Agriculture, Agricultural Research Service National Clonal Germplasm Repository in Corvallis, OR (Hummer, 2001). Furthermore, we have started to construct a core collection of $C$. heterophylla to better use the resource. Compared with $C$. avellana, $C$. heterophylla is adapted to regions with low temperature $\left(-30\right.$ to $\left.-40{ }^{\circ} \mathrm{C}\right)$ and drought conditions. As is well known, most $C$. avellana cultivars are susceptible to eastern filbert blight, but the causal fungus Anisogramma anomala is not present in China. Chinese scientists made controlled pollinations between selected plants of $C$. heterophylla as female parents and C. avellana as the male parents (Wang et al., 2018). The first generation hybrids of $C$. heterophylla $\times C$. avellana are called Ping'ou hybrid hazelnuts and $\approx 14$ cultivars have been selected in China. In view of the successful hybridization of $C$. heterophylla $\times C$. avellana, more potential resources of $C$. heterophylla and $C$. kweichowensis need further hybrid utilization. In addition, we can preserve high genetic diversity populations in situ. Based on our data (Table 4), the WC, MS, and WA populations of $C$. heterophylla, and YX, ZP, LA, and TB populations of $C$. kweichowensis with high allelic richness should be preserved in situ.

In summary, our studies showed a relatively high level of genetic diversity among $C$. heterophylla and $C$. kweichowensis populations in China. According to their morphological characteristics, geographic distributions, habitat differences, and reproductive isolation of $C$. heterophylla and $C$. kweichowensis, they are considered as independent species (Ma et al., 2014; Qi, 1996; Zhang et al., 2005). The UPGMA, STUCTURE, and PCoA analysis gave a similar result, showing that $C$. heterophylla and $C$. kweichowensis populations were clearly separated, which better clarifies their taxonomic relationships. To maximize the protection of the diversity of these two hazelnut species, the WC, MS, and WA populations of $C$. heterophylla, and YX, ZP, LA, and TB populations of $C$. kweichowensis should be priority preserved in situ. In addition, the results will provide valuable information for conservation strategy, breeding, and utilization.

\section{Literature Cited}

Barbará, T., C. Palma-Silva, G.M. Paggi, F. Bered, M.F. Fay, and C. Lexer. 2007. Cross-species transfer of nuclear microsatellite markers: Potential and limitations. Mol. Ecol. 16:3759-3767.

Bassil, N., P. Boccacci, R. Botta, J. Postman, and S.A. Mehlenbacher. 2013. Nuclear and chloroplast microsatellite markers to assess genetic diversity and evolution in hazelnut species, hybrids and cultivars. Genet. Resources Crop Evol. 60:543-568.

Bassil, N., R. Botta, and S.A. Mehlenbacher. 2005. Microsatellite markers in hazelnut: Isolation, characterization, and cross-species amplification. J. Amer. Soc. Hort. Sci. 130:543-549.

Boccacci, P., A. Akkak, and R. Botta. 2006. DNA typing and genetic relations among european hazelnut (Corylus avellana L.) cultivars using microsatellite markers. Genome 49:598-611.

Boccacci, P., R. Botta, and M. Rovira. 2008. Genetic diversity of hazelnut (Corylus avellana L.) germplasm in northeastern Spain. HortScience 43:667-672.

Chen, R. 1953. China tree taxonomy. China Book Distribution Co., Nanjing, China.

Demchik, M., A. Kern, L. Braun, J. Fischbach, and K. Turnquist. 2018. Genetic diversity of american hazelnut in the upper midwest USA. Agrofor. Syst. 92:1507-1516.

Doyle, J.J. and J.L. Doyle. 1987. A rapid DNA isolation procedure for small quantities of fresh leaf tissue. Phytochem. Bull. 19:11-15.

Earl, D.A. and B.M. Vonholdt. 2012. STRUCTURE HARVESTER: A website and program for visualizing STRUCTURE output and implementing the Evanno method. Conserv. Genet. Resour. 4:359361.

Evanno, G., S. Regnaut, and J. Goudet. 2005. Detecting the number of clusters of individuals using the software STRUCTURE: A simulation study. Mol. Ecol. 14:2611-2620.

Ferrari, M., M. Gori, R. Monnanni, M. Biuatti, G.T.S. Mugnozza, and C.D. Pace. 2005. DNA fingerprinting of Corylus avellana L. accessions revealed by AFLP molecular markers. Acta Hort. 686:125134.

Food and Agriculture Organization of the United Nations. 2017. FAOSTAT. Compare data. 1 Aug. 2017. <http://www.fao.org/ faostat/en/\#compare>.

Galderisi, U., M. Cipollaro, G.D. Bernardo, L.D. Masi, G. Galano, and A. Cascino. 1999. Identification of hazelnut (Corylus avellana) cultivars by RAPD analysis. Plant Cell Rep. 18:652-655.

Gökirmak, T., S.A. Mehlenbacher, and N.V. Bassil. 2009. Characterization of European hazelnut (Corylus avellana) cultivars using SSR markers. Genet. Resources Crop Evol. 56:147-172.

Gürcan, K., S.A. Mehlenbacher, R. Botta, and P. Boccacci. 2010a. Development, characterization, segregation, and mapping of microsatellite markers for European hazelnut (Corylus avellana L.) from enriched genomic libraries and usefulness in genetic diversity studies. Tree Genet. Genomes 6:513-531.

Gürcan, K., S.A. Mehlenbacher, and V. Erdoğan. 2010b. Genetic diversity in hazelnut (Corylus avellana L.) cultivars from Black Sea countries assessed using SSR markers. Plant Breed. 129:422-434.

Hamrick, J. and M.J.W. Godt. 1996. Effects of life history traits on genetic diversity in plant species. Philos. Trans. R. Soc. Lond. B Biol. Sci. 351:1291-1298.

Hummer, K.E. 2001. Hazelnut genetic resources at the Corvallis repository. Acta Hort. 556:21-24.

Kafkas, S., Y. Doğan, A. Sabir, A. Turan, and H. Seker. 2009. Genetic characterization of hazelnut (Corylus avellana L.) cultivars from Turkey using molecular markers. HortScience 44:1557-1561.

Kalinowski, S.T., M.L. Taper, and T.C. Marshall. 2007. Revising how the computer program Cervus accommodates genotyping error increases success in paternity assignment. Mol. Ecol. 16:1099-1106. Liang, W.J. 1988. Discussion on the taxonomic status of Corylus kweichowensis and its new varieties. Plant Res. 4:117-119.

Ma, Q.H., H.L. Huo, X. Chen, T.T. Zhao, W.J. Liang, and G.X. Wang. 2014. Study on the taxonomy, distribution, development and 
utilization of Corylus kweichowensis Hu. J. Plant Genet. Resources 15:1223-1231.

Martins, S., F. Simões, J. Matos, A.P. Silva, and V. Carnide. 2014. Genetic relationship among wild, landraces and cultivars of hazelnut (Corylus avellana L.) from Portugal revealed through ISSR and AFLP markers. Plant Syst. Evol. 300:1035-1046.

Mayr, E. 1999. Systematics and the origin of species from the viewpoint of a zoologist. Harvard Univ. Press, Cambridge, MA.

Miaja, M.L., R. Vallania, C. Me, A. Akkak, O. Nassi, and G. Lepori. 2001. Varietal characterization in hazelnut by RAPD markers. Acta Hort. 556:247-250.

Michalski, S.G. and W. Durka. 2007. High selfing and high inbreeding in peripheral populations of Juncus atratus. Mol. Ecol. 16:47154727.

Molnar, T. 2011. Corylus L., p. 15-48. In: C. Kole (ed.). Wild crop relatives: Genomic and breeding resources of forest trees. Vol. 10. Springer-Verlag, Berlin, Germany.

Nei, M. 1972. Genetic distance between populations. Amer. Nat. 106:283-292.

Peakall, R. and P. Smouse. 2012. GenAlEx 6.5: Genetic analysis in Excel. Population genetic software for teaching and research-an update. Bioinformatics 28:2537-2539.

Qi, J.Z. 1996. Study on taxonomy of Corylus kweichowensis. J. Nanjing For. Univ. 20:71-74.

Rowley, E.R., R. VanBuren, D.W. Bryant, H.D. Priest, S.A. Mehlenbacher, and T.C. Mockler. 2018. A draft genome and high-density genetic map of european hazelnut (Corylus avellana L.). bioRxiv 469015 doi: https://doi.org/10.1101/469015.

Sathuvalli, V.R. and S.A. Mehlenbacher. 2012. Characterization of american hazelnut (Corylus americana) accessions and Corylus americana $\times$ Corylus avellana hybrids using microsatellite markers. Genet. Resources Crop Evol. 59:1055-1075.

Sathuvalli, V.R. and S.A. Mehlenbacher. 2013. De novo sequencing of hazelnut bacterial artificial chromosomes (BACs) using multiplex Illumina sequencing and targeted marker development for eastern filbert blight resistance. Tree Genet. Genomes 9:11091118 .
Sharma, P.C., A. Grover, and G. Kahl. 2007. Mining microsatellites in eukaryotic genomes. Trends Biotechnol. 25:490-498.

Slatkin, M. 1985. Rare alleles as indicators of gene flow. Evolution 39:53-65.

Slatkin, M. and N.H. Barton. 1989. A comparison of three indirect methods for estimating average levels of gene flow. Evolution 43:1349-1368.

Tamura, K., G. Stecher, D. Peterson, A. Filipski, and S. Kumar. 2013. MEGA6: Molecular evolutionary genetics analysis version 6.0. Mol. Biol. Evol. 30:2725-2729.

Wang, G.X., Q.H. Ma, T.T. Zhao, and L.S. Liang. 2018. Resources and production of hazelnut in China. Acta Hort. 1226:59-63.

Wang, Y.M., S.C. Su, M.P. Zha, L.L. Cheng, W.G. Huang, and T.X. Ma. 2008. Genetic analysis of genus Corylus in China by SSR. J. Northeast For. Univ. 11:48-51.

Wright, S. 1978. Variability within and among natural populations. Univ. Chicago Press, Chicago, IL.

Yang, Z., G.X. Wang, Q.H. Ma, W.X. Ma, L.S. Liang, and T.T. Zhao. 2019. The complete chloroplast genomes of three Betulaceae species: Implications for molecular phylogeny and historical biogeography. PeerJ 7:e6320.

Yeh, F.C., R. Yang, and T. Boyle. 1999. Popgene version 1.32. Microsoft Windows-based freeware for population genetic analysis. Univ. Alberta, Edmonton, AB, Canada.

Zhang, Y.H., L. Liu, W.J. Liang, and Y.M. Zhang. 2005. China fruit's monograph-chestnut and hazelnut volume. China Forestry Publishing House, Beijing, China.

Zhao, S., S.C. Su, Z.G. Chen, S.Y. Sheng, and Z. Wang. 2016. An assessment of the genetic diversity and population genetic structure concerning the Corylus heterophylla Fisch., grown in the Tieling district of Liaoning Province using SSR markers. J. Fruit Sci. 33:24-33.

Zheng, W.J. 1985. Tree records of China (volume II). China Forestry Publishing House, Beijing, China.

Zong, J.W., T.T. Zhao, Q.H. Ma, L.S. Liang, and G.X. Wang. 2015. Assessment of genetic diversity and population genetic structure of Corylus mandshurica in China using SSR markers. PLoS One 10:e0137528. 
Supplemental Table 1. Geographical parameters and climate types of Corylus heterophylla, Corylus kweichowensis, and Corylus yunnanensis.

\begin{tabular}{lccc}
\hline Corylus species & Latitude $\left({ }^{\circ} \mathrm{N}\right)$ & Longitude $\left({ }^{\circ} \mathrm{E}\right)$ & Climate type \\
\hline C. heterophylla & $36.78-51.73$ & $100.57-132.20$ & Temperate \\
C. kweichowensis & $26.48-36.97$ & $102.10-121.43$ & Warm temperate, subtropical \\
C. yunnanensis & $21.13-29.25$ & $98.50-104.87$ & Subtropical \\
\hline
\end{tabular}

Supplemental Table 2. Phenotypic characteristics of Corylus heterophylla, Corylus kweichowensis, and Corylus yunnanensis.

\begin{tabular}{lccc}
\hline Phenotypic characteristics $^{\mathrm{z}}$ & C. heterophylla & C. kweichowensis & C. yunnanensis \\
\hline Tree height $(\mathrm{m})$ & 3 & 9 & 3 \\
Pubescence on young branches & Sparse & Sparse & 0.70 \\
Leaf index & 0.84 & 1.02 & 0.82 \\
Petiole length $(\mathrm{cm})$ & 1.38 & Dense & 0.64 \\
Pubescence on the adaxial side of the leaf & Sparse & 8.6 & Dense \\
Leaf vein number & 6.0 & 1.07 & 1.9 \\
Length index of husk & 1.81 & 1.07 & 1.38 \\
Nut shape index & 0.93 & Obtuse & 0.83 \\
Bud tip shape & Obtuse & Obtuse &
\end{tabular}

${ }^{\mathrm{z} P h e n o t y p i c ~ c h a r a c t e r i s t i c s ~ d e s c r i b e d ~ b y ~ Q i ~(1996) . ~}$

Supplemental Table 3. Characterization of 11 simple sequence repeat (SSR) markers including locus, primer sequence, repeat motif, melting temperature $(\mathrm{Tm})$, and product size among Corylus species.

\begin{tabular}{|c|c|c|c|c|}
\hline SSR locus & Primer sequence $\left(5^{\prime}\right.$ to $\left.3^{\prime}\right)$ & Repeat motif & $\operatorname{Tm}\left({ }^{\circ} \mathrm{C}\right)$ & Size (base pairs) \\
\hline \multirow[t]{2}{*}{$\overline{\mathrm{CAC}-\mathrm{B} 005^{\mathrm{z}}}$} & CAAACTTATGATAGGCATGCAA & (GA)22 & 51 & $270-280$ \\
\hline & TGTCACTTTGGAAGACAAGAGA & & & \\
\hline CAC-B105 & AAAGGAGCAAGCATGTTAGG & (GA)16 & 51 & $130-160$ \\
\hline \multirow[t]{2}{*}{$\mathrm{CAC}-\mathrm{B} 001^{\mathrm{z}}$} & CСAAATCAAAACAACCAAACC & $(\mathrm{GA}) 18$ & 50 & $98-120$ \\
\hline & CCGCAGCCATCACATCTA & & & \\
\hline $\mathrm{CAC}-\mathrm{B} 028^{\mathrm{z}}$ & ATGGACGAGGAATATTTCAGC & (AG)16 & 51 & $260-280$ \\
\hline \multirow[t]{2}{*}{$\mathrm{CAC}-\mathrm{B} 113^{\mathrm{z}}$} & TTGAGGAAGTCCAGGAAAAT & $(\mathrm{GA}) 14$ & 51 & $148-180$ \\
\hline & GCCAGAGAGAGCAAGAGTTAG & & & \\
\hline \multirow[t]{2}{*}{$\mathrm{CAC}-\mathrm{C} 003^{\mathrm{z}}$} & CCGCTAAGCTGGTAGGTAGT & $(\mathrm{AGG}) 9$ & 48 & $100-130$ \\
\hline & CGGTGCATCAAGTTGTACTT & & & \\
\hline \multirow[t]{2}{*}{$\mathrm{CAC}-\mathrm{C} 028^{\mathrm{z}}$} & CTACCCCATCGCTTGACAC & $(\mathrm{GAA}) 10$ & 51 & $120-150$ \\
\hline & GGAGACTTGTTTGCCACAGA & & & \\
\hline \multirow[t]{2}{*}{ LG637y } & GCTTAATTGATTGCCTTGGGTA & (TC) 18 & 60 & $230-252$ \\
\hline & GTTTCCATGTTTGGGTTGTAGG & & & \\
\hline \multirow[t]{2}{*}{ LG639y } & ATAAACCCAACTTCAGCGTCAT & $(\mathrm{ATGT}) 6$ & 60 & $217-235$ \\
\hline & CACTCTCACAGATCCACCAAAG & & & \\
\hline
\end{tabular}

${ }^{\mathrm{z}} \mathrm{SSR}$ primers developed by Bassil et al. (2005).

${ }^{\mathrm{y}}$ SSR primers developed by Sathuvalli and Mehlenbacher (2013). 
Supplemental Table 4. Unique alleles at 11 simple sequence repeat (SSR) loci between 21 Corylus heterophylla and 13 Corylus kweichowensis populations.

\begin{tabular}{|c|c|c|c|c|}
\hline \multirow[b]{2}{*}{ Locus } & \multicolumn{2}{|c|}{ C. heterophylla } & \multicolumn{2}{|c|}{ C. kweichowensis } \\
\hline & Unique alleles (base pairs) & Population $\operatorname{code}^{\mathrm{z}}$ & Unique alleles (base pairs) & Population $\operatorname{code}^{\mathrm{z}}$ \\
\hline \multirow[t]{2}{*}{$\overline{\mathrm{CAC}-\mathrm{B} 005^{\mathrm{y}}}$} & 270 & $\mathrm{TL}$ & 268 & $\mathrm{LD}$ \\
\hline & & & 272 & TB \\
\hline & & & 178 & $\mathrm{ZP}$ \\
\hline & & & 168 & LA \\
\hline \multirow[t]{4}{*}{ CAC-B001 } & & & 90 & ES \\
\hline & & & 120 & LA \\
\hline & & & 84 & HSS \\
\hline & & & 88 & HSS \\
\hline \multirow[t]{3}{*}{ CAC-B028y } & 274 & GJ & 252 & $\mathrm{ZP}$ \\
\hline & 280 & GJ & & \\
\hline & 250 & WA & & \\
\hline \multirow{2}{*}{$\mathrm{CAC}-\mathrm{C} 028^{\mathrm{y}}$} & 123 & WC & 123 & ES \\
\hline & & & 151 & LD \\
\hline LG612 ${ }^{\mathrm{x}}$ & & & 243 & XW \\
\hline \multirow[t]{2}{*}{ LG628x } & 236 & HR & & \\
\hline & 226 & LQ & & \\
\hline LG637 $7^{x}$ & 226 & LQ & 230 & $\mathrm{XE}$ \\
\hline \multirow[t]{2}{*}{$\mathrm{LG}^{\mathrm{x}}$} & 247 & MS & 251 & HS \\
\hline & 201 & LQ & & \\
\hline
\end{tabular}

${ }^{\mathrm{z}}$ The population codes are listed in Table 1 .

${ }^{\mathrm{y}} \mathrm{SSR}$ primers developed by Bassil et al. (2005).

${ }^{\mathrm{x}}$ SSR primers developed by Sathuvalli and Mehlenbacher (2013). 